\title{
Sexual behaviour of young people and the risk of HIV infection
}

\author{
CAMERON BOWIE ${ }^{1}$ AND NICHOLAS FORD ${ }^{2}$ \\ From 'Somerset Health Authority, County Hall, Taunton; and ${ }^{2}$ Institute of Population Studies, University of \\ Exeter
}

\begin{abstract}
A survey of 16-21 year old people in Somerset was undertaken to find out about their sexual behaviour prior to mounting a local education campaign on AIDS. A representative sample of 400 people, using quota sampling in 40 randomly selected electoral wards, completed a schedule structured part self administered questionnaire. Of these, 371 (92\%) considered themselves heterosexual. Nearly half $(47 \%)$ of the 16 year olds had engaged in sexual intercourse, rising to $89 \%$ by the age of 21 . Mean frequency of sexual intercourse among the sexually active is 62 per year. The frequency of partner change decreases with increasing age for non-virgins from $2 \cdot 1$ for 16 year olds to 1.5 partner changes per year for 21 year olds (mean frequency 1.7 per year, ie, a new partner every 7 months). This level of sexual activity could eventually give rise to HIV prevalence rates similar to those found in Africa, ie, 15-100 HIV antibody positive per 1000.
\end{abstract}

Predictions about the scale of the AIDS epidemic are limited by the sparsity of information about sexual activity in young people. ${ }^{1}$ Various mathematical models have been proposed to predict the spread of infection, and the imminent and ultimate numbers of infected people in the various low and high risk groups. $^{2}$ For instance using a mathematical model to predict equilibrium levels of the prevalence of HIV infection, and making various assumptions about sexual behaviour, $\mathrm{Knox}^{3}$ has estimated for heterosexual males and females (with rates of 0.7 and 0.6 changes of partner per year) prevalence rates of 15 and 66 per 1000 respectively. His model, like any other, simplifies the complexities of the situation, and broad assumptions have had to be made about the size and sexual activity of groups with different sexual behaviour. These assumptions about sexual behaviour are based on limited information: the only UK derived data are qualitative; quantitative data are from the USA in the 1940s (Kinsey ${ }^{4}$ ). Essential information required to make predictions about the spread of AIDS includes estimates of risk of transmission of the virus by an infected person and the number of partners that person has had. Transmission risk depends on infectivity of the virus and frequency of sexual intercourse.

A survey of 16-21 year old people in Somerset was undertaken to compare sexual behaviour with the assumptions about sexual behaviour used in mathematical models, and to facilitate the prediction of future prevalence rates of HIV infection. The survey was also intended to provide guidance about health education on AIDS for this age group.

\section{Methods}

A schedule structured part self administered questionnaire was used to interview 400 people aged 16-21 years in Somerset Health District in July 1987. A pure random sampling strategy was rejected because of expense, in place of quota sampling of ten young adults from 40 randomly selected electoral wards. The wards were chosen with probability of selection proportional to the estimated current 16-21 population in each ward as derived from 1981 census data. Within each selected ward, interlocking quota samples of two age groups, 16-18 and 19-21 years, with equal numbers of both sexes, were used by trained field workers for the selection of the 10 respondents. Only one person per household was interviewed, and the interviews were carried out in the respondent's home, mainly in the late afternoon and early evening in order to ensure that a sufficient proportion of respondents in employment was selected.

The questionnaire was in two parts; the first part, covering questions on sociodemographic characteristics, AIDS awareness and sexual attitudes, involved the interviewers asking questions of the respondent and recording the answers; the second part, covering questions on sexual behaviour, was 
given to the respondent for self completion. The second part was completed in the presence of the interviewer who did not see the answers, since once completed the questionnaire was placed in an envelope, sealed and handed back to the interviewer.

Ninety five per cent of eligible contacts agreed to be interviewed, with most of those who declined claiming to do so because of lack of available time. The interview took between 25 and 40 minutes to administer. The questionnaire included predominantly fixed format questions. In order to enhance the reliability of the responses to some of the more complex questions, for instance concerning attitudes to sexual behaviour, some questions were approached from different angles within the structured format.

The results about sexual orientation and experience, and age of first intercourse, relate to the whole sample. The results about partners, frequency of intercourse and condom use relate to non-virgins only. For each individual the frequency of partner change was calculated by dividing the number of lifetime partners by the period of sexual experience in years.

Results about knowledge, attitudes, perception of risk and anticipated behaviour are reported separately. ${ }^{5}$

\section{Results}

REPRESENTATIVENESS OF THE SAMPLE

We analysed 400 questionnaires. Of the 400 respondents, 199 were male and 201 female. In this age range $53 \%$ of the population are male; the disproportionate number of males in the sample is partly explained by the number of (mostly male) public schools in Somerset. Only residents of domestic type accommodation were potential candidates for admission to the survey. Fifty five per cent of the sample were aged $16-18$ compared with $53 \%$ in the population aged 16-21. The sample figures are not significantly different from the population proportions, using simple $\chi^{2}$ tests. However, $27 \%$ were full time students and $15 \%$ unemployed persons (excluding those on job creation schemes, etc), compared with population estimates of about $20 \%$ and $8 \%$ respectively, a statistically significant difference $(p<0.001)$. The employment of survey respondents is self reported and therefore open to some error, but it does appear that people who are likely to be at home more of the time are over represented despite efforts to call at home during the early evening. As reported later, the employed persons were found to be more sexually active than the unemployed and students, so there may be slight underrepresentation in the overall estimates of sexual activity for the population.
Possibly the most important indicator of representativeness is social class. This was determined by occupation of head of households. Table 1 gives the distribution for the sample compared to the social class distribution for head of households at the time of the 1981 census. In both cases "retired" households, "unemployed" and "unknown" etc, numbering 21 in the sample, have been removed to allow easier comparability. Apart from a slightly lower number in the sample for class II (managerial) and slightly more in class IIIm (skilled manual) the distributions agree quite closely $\left(\chi^{2} 10.87, p>0.05\right)$.

Table 1 Social class distribution

\begin{tabular}{lcc}
\hline Social class & Sample & $\begin{array}{l}\text { Somerset, } \\
1981 \text { Census }\end{array}$ \\
\hline I & $6 \%$ & $6 \%$ \\
II & $21 \%$ & $28 \%$ \\
III nm & $13 \%$ & $13 \%$ \\
III m & $37 \%$ & $32 \%$ \\
IV & $17 \%$ & $17 \%$ \\
V & $6 \%$ & $4 \%$ \\
\hline
\end{tabular}

SEXUAL BEHAVIOUR

Ninety-two per cent of the young adults considerecB themselves to be heterosexual, $2 \%$ either bisexual op homosexual and a further $5 \%$ were uncertain of thein sexual orientation, of whom half were sexually $\frac{0}{5}$ experienced. Seventy per cent were non-virgins; $47 \%$ of 16 year olds had engaged in sexual intercourse? rising to $89 \%$ by the age of 21 (table 2). First sexual intercourse rarely occurred before 14 years of age $(8 \%$ of boys and $4 \%$ of girls) (table 3 ).

Table 2 Number and proportion (\%) of sexually experienced 16-21 year olds by age and gender

\begin{tabular}{|c|c|c|c|c|c|c|}
\hline \multirow[b]{2}{*}{ Present age } & \multicolumn{4}{|c|}{ Sexually experienced } & \multicolumn{2}{|c|}{ Total sample } \\
\hline & $\begin{array}{l}\text { Male } \\
n\end{array}$ & $(\%)$ & $\begin{array}{l}\text { Female } \\
n\end{array}$ & $(\%)$ & $\begin{array}{l}\text { Male } \\
n\end{array}$ & $\begin{array}{l}\text { Female } \\
n\end{array}$ \\
\hline 16 & 22 & (45) & 25 & (49) & 49 & 51 \\
\hline 17 & 18 & (67) & 26 & (72) & 27 & 36 \\
\hline 18 & 22 & (67) & 21 & (75) & 32 & 28 \\
\hline 19 & 23 & (70) & 28 & (78) & 33 & 36 \\
\hline 20 & 17 & (89) & 28 & (88) & 19 & 32 \\
\hline 21 & 36 & (92) & 15 & (83) & 39 & 18 \\
\hline Total & 138 & (69) & 143 & (71) & 199 & 201 \\
\hline
\end{tabular}

The majority were sexually active on a regular basis: $48 \%$ of the non-virgins had engaged in sexual intercourse during the last week rising to $66 \%$ during the last month (table 4). Frequency of sexual intercourse was measured by reference to the last 
month, with three roughly equal groups: not at all, 1-5 times, and 6 or more times during the month (table 4). From the frequency during the survey month the estimated annual mean frequency of sexual intercourse among the sexually active is 62 per year.

Table 3 Age of first sexual intercourse (non-virgins only) by gender (\%)

\begin{tabular}{llrrrr}
\hline & $\begin{array}{l}\text { Age at Ist } \\
\text { intercourse } \\
\text { (years) }\end{array}$ & $\begin{array}{l}\text { Males } \\
n\end{array}$ & $(\%)$ & \multicolumn{4}{c}{$\begin{array}{l}\text { Females } \\
n\end{array}$} & $(\%)$ \\
\hline & $<13$ & 5 & $(4)$ & 1 & $(1)$ \\
& 13 & 9 & $(7)$ & 6 & $(5)$ \\
& 14 & 14 & $(11)$ & 9 & $(7)$ \\
& 15 & 27 & $(22)$ & 30 & $(23)$ \\
& 16 & 23 & $(19)$ & 46 & $(35)$ \\
& 17 & 22 & $(18)$ & 23 & $(18)$ \\
Subtotal & 18 & 13 & $(10)$ & 8 & $(6)$ \\
Question not & 19 & 9 & $(7)$ & 7 & $(5)$ \\
answered & 20 & 2 & $(2)$ & 0 & \\
$\begin{array}{c}\text { Total } \\
\text { non-virgins }\end{array}$ & & 124 & $(100)$ & 130 & $(100)$ \\
& & 14 & & & \\
\hline
\end{tabular}

For $84 \%$ the most recent sexual experience had taken place with a steady partner (table 4). The sexual partners of males are predominately $(46 \%)$ their own age, with equal numbers older and younger. The partners of females however are generally older than themselves $(78 \%$ one year older or more).

Forty six per cent of the sample had had two or more partners in their lives (table 5). Males and the older age groups generally had more sexual partners than females and the younger groups. Only $5 \%$ of the total sample had four or more partners in the previous 12 months (table 6).

The frequency of partner change decreases with increasing age, from $2 \cdot 1$ to 1.5 partner changes per year (table 7). The mean frequency for the sexually active group is 1.7 per year (ie, a new partner every 7 months). For the whole sample, including virgins and non-virgins, the frequency is 1.1 partner changes per year.

Condom usage - Three quarters of non-virgins had used a condom at some point in their sexual history, but only $36 \%$ had used one during their last intercourse, and only $40 \%$ intended to use a condom during their next sexual intercourse (table 6). Although there were no statistically significant

Table 4 Period of time since last sexual intercourse, frequency of sexual intercourse in last month and relationship with most recent partner (non-virgins only) (\%)

\begin{tabular}{|c|c|c|c|c|c|c|c|c|}
\hline & $\begin{array}{l}\text { Males } \\
n\end{array}$ & $(\%)$ & $\begin{array}{l}\text { Females } \\
n\end{array}$ & $(\%)$ & $\begin{array}{l}16-1 \\
n\end{array}$ & $(\%)$ & $\begin{array}{l}19-2 \\
n\end{array}$ & $(\%)$ \\
\hline \multicolumn{9}{|l|}{ Period of time since last } \\
\hline $0-7$ days & 51 & (43) & 64 & (52) & 53 & (45) & 62 & (50) \\
\hline 8 days -1 month & 19 & (16) & 26 & (21) & 20 & (17) & 25 & (20) \\
\hline 1-3 months & 9 & (8) & 9 & (7) & 12 & (10) & 6 & (5) \\
\hline 3 months-1 year & 31 & (26) & 18 & (15) & 27 & (23) & 22 & (18) \\
\hline$>1$ year & 9 & (8) & 6 & (5) & 7 & (6) & 8 & (7) \\
\hline Subtotal & 119 & (100) & 123 & (100) & 119 & $(100)$ & 123 & (100) \\
\hline Question not answered & 19 & & 20 & & 15 & & 24 & \\
\hline \multicolumn{9}{|l|}{ Frequency in last month } \\
\hline 0 & 54 & (44) & 36 & (28) & 46 & (35) & 44 & (34) \\
\hline $1-2$ & 16 & (13) & 17 & (13) & 22 & (17) & 11 & (8) \\
\hline $3-5$ & 18 & (15) & 27 & (21) & 21 & (16) & 24 & (18) \\
\hline $6-10$ & 13 & (10) & 31 & (24) & 18 & (14) & 26 & (20) \\
\hline $11-20$ & 17 & (14) & 16 & (12) & 14 & (11) & 19 & (15) \\
\hline$>20$ & 6 & (5) & 3 & (2) & 2 & (2) & 7 & (5) \\
\hline Subtotal & 124 & (100) & 130 & (100) & 123 & $(100)$ & 131 & (100) \\
\hline Question not answered & 14 & & 13 & & 11 & & 16 & \\
\hline \multicolumn{9}{|c|}{ Relationship with most recent } \\
\hline Spouse & 5 & (4) & 7 & (5) & 1 & (1) & 11 & (8) \\
\hline Fiancé(e) & 9 & (7) & 20 & (15) & 12 & (10) & 17 & (13) \\
\hline Steady partner & 86 & (69) & 89 & (68) & 86 & (69) & 89 & (67) \\
\hline Other & 25 & (20) & 15 & (11) & 25 & (20) & 15 & (11) \\
\hline Subtotal & 125 & $(100)$ & 131 & $(100)$ & 124 & $(100)$ & 132 & (100) \\
\hline Question not answered & 13 & & 12 & & 10 & & 15 & \\
\hline Total non-virgins & 138 & & 143 & & 134 & & 147 & \\
\hline
\end{tabular}


Table 5 Number of sexual partners in lifetime by gender, age group and emptoyment status (\%)

\begin{tabular}{|c|c|c|c|c|c|c|c|c|c|c|c|c|c|c|}
\hline \multirow{2}{*}{$\begin{array}{l}\text { Number of } \\
\text { partners }\end{array}$} & \multirow{2}{*}{$\begin{array}{l}\text { Gender } \\
\text { Males } \\
n\end{array}$} & \multirow{2}{*}{$(\%)$} & \multicolumn{2}{|c|}{ Females } & \multicolumn{2}{|c|}{$\begin{array}{l}\text { Age group } \\
16-18\end{array}$} & \multicolumn{2}{|l|}{$19-21$} & \multicolumn{2}{|c|}{ Students } & \multicolumn{2}{|c|}{$\begin{array}{l}\text { Housewives } \\
\text { and unemployed* }\end{array}$} & \multicolumn{2}{|c|}{ Employed } \\
\hline & & & $n$ & $(\%)$ & $n$ & $(\%)$ & $n$ & $(\%)$ & $n$ & $(\%)$ & $n$ & $(\%)$ & $n$ & $(\%)$ \\
\hline $\begin{array}{l}0 \\
1 \\
2 / 3 \\
4 \text { or more }\end{array}$ & $\begin{array}{l}61 \\
37 \\
33 \\
55\end{array}$ & $\begin{array}{l}(33) \\
(20) \\
(18) \\
(30)\end{array}$ & $\begin{array}{l}58 \\
45 \\
46 \\
38\end{array}$ & $\begin{array}{l}(31) \\
(24) \\
(25) \\
(20)\end{array}$ & $\begin{array}{l}89 \\
51 \\
36 \\
37\end{array}$ & $\begin{array}{l}(42) \\
(24) \\
(17) \\
(17)\end{array}$ & $\begin{array}{l}30 \\
31 \\
49 \\
56\end{array}$ & $\begin{array}{l}(18) \\
(19) \\
(30) \\
(34)\end{array}$ & $\begin{array}{r}60 \\
20 \\
15 \\
9\end{array}$ & $\begin{array}{r}(58) \\
(19) \\
(14) \\
(9)\end{array}$ & $\begin{array}{l}27 \\
22 \\
27 \\
30\end{array}$ & $\begin{array}{l}(26) \\
(21) \\
(26) \\
(29)\end{array}$ & $\begin{array}{l}32 \\
40 \\
37 \\
54\end{array}$ & $\begin{array}{l}(20) \\
(25) \\
(23) \\
(33)\end{array}$ \\
\hline $\begin{array}{l}\text { Question not } \\
\text { answered }\end{array}$ & 13 & & 14 & & 10 & & 11 & & 5 & & 9 & & 13 & \\
\hline Total sample & 199 & & 201 & & 223 & & 177 & & 109 & & 115 & & 176 & \\
\hline
\end{tabular}

*Includes 15 housewives

Table 6 Condom usage (non-virgins only) (\%)

\begin{tabular}{|c|c|c|c|c|c|c|c|c|c|c|c|c|c|}
\hline & & \multicolumn{12}{|c|}{ Sexual partners in last 12 months } \\
\hline & & \multicolumn{2}{|c|}{ Males } & \multicolumn{2}{|c|}{ Females } & \multicolumn{2}{|l|}{0} & \multicolumn{2}{|l|}{1} & \multicolumn{2}{|l|}{$2 / 3$} & \multicolumn{2}{|c|}{4 or more } \\
\hline & & $n$ & $(\%)$ & $n$ & $(\%)$ & $n$ & $(\%)$ & $n$ & $(\%)$ & $n$ & $(\%)$ & $n$ & $(\%)$ \\
\hline Ever used a condom & $\begin{array}{l}\text { Yes } \\
\text { No/not sure }\end{array}$ & $\begin{array}{l}93 \\
34\end{array}$ & (73) & $\begin{array}{r}101 \\
34\end{array}$ & (75) & $\begin{array}{r}14 \\
9\end{array}$ & (61) & $\begin{array}{r}111 \\
35\end{array}$ & (76) & $\begin{array}{l}40 \\
14\end{array}$ & (74) & $\begin{array}{r}14 \\
4\end{array}$ & (78) \\
\hline $\begin{array}{l}\text { Used a condom in most } \\
\text { recent sexual intercourse }\end{array}$ & $\begin{array}{l}\text { Yes } \\
\text { No/not sure }\end{array}$ & $\begin{array}{l}45 \\
80\end{array}$ & (36) & $\begin{array}{l}49 \\
86\end{array}$ & (36) & $\begin{array}{l}10 \\
11\end{array}$ & (48) & $\begin{array}{l}52 \\
94\end{array}$ & (36) & $\begin{array}{l}16 \\
38\end{array}$ & (30) & $\begin{array}{r}3 \\
15\end{array}$ & (17) \\
\hline $\begin{array}{l}\text { Intend to use condom during } \\
\text { next sexual intercourse }\end{array}$ & $\begin{array}{l}\text { Yes } \\
\text { No/not sure }\end{array}$ & $\begin{array}{l}49 \\
77\end{array}$ & (39) & $\begin{array}{l}56 \\
79\end{array}$ & (41) & $\begin{array}{l}11 \\
12\end{array}$ & (48) & $\begin{array}{l}61 \\
84\end{array}$ & $(42)$ & $\begin{array}{l}19 \\
35\end{array}$ & (35) & $\begin{array}{r}3 \\
15\end{array}$ & (17) \\
\hline $\begin{array}{l}\text { Intend to use condom during } \\
\text { next sexual intercourse } \\
\text { with a new partner }\end{array}$ & $\begin{array}{l}\text { Yes } \\
\text { No/not sure }\end{array}$ & $\begin{array}{l}66 \\
65\end{array}$ & $(50)$ & $\begin{array}{l}97 \\
43\end{array}$ & (69) & $\begin{array}{l}13 \\
10\end{array}$ & (57) & $\begin{array}{r}101 \\
47\end{array}$ & (68) & $\begin{array}{l}28 \\
29\end{array}$ & (49) & $\begin{array}{r}5 \\
12\end{array}$ & (29) \\
\hline Total non-virgins* & & 138 & & 143 & & 24 & & 153 & & 59 & & 18 & \\
\hline
\end{tabular}

differences in these findings by gender or age group, strong differences emerged according to the number of sexual partners an individual had had in the last 12 months. Whilst $68 \%$ of those with one sexual partner in the last 12 months intended to use a condom in the next sexual intercourse with a new partner, the figure dropped to $29 \%$ for those who had had four or more partners.

\section{Discussion}

The use of quota sampling within a random selection of electoral wards provides an economical method of surveying, while attaining a representative sample of 16-21 year olds in terms of age, sex, social class, and employment status. The questionnaire was well received. It is not possible to know how truthfully questions were answered. Reservations have often been expressed concerning the difficulties of obtaining accurate and reliable data on sexual behaviour and attitudes. ${ }^{6}$ The very low refusal rate $(5 \%)$ and noncompletion of the behaviour section of the questionnaire ( 2 out of 400 ), and the low level of inconsistent answers allows reasonable confidence in the overall reliability of the data.
Table 7 Average number of new partners per year for non-virgins only

\begin{tabular}{llllll}
\hline & & \multicolumn{5}{c}{ Both sexes } \\
\cline { 5 - 6 } Age & $\begin{array}{l}\text { Male } \\
\text { (Mean) }\end{array}$ & $\begin{array}{l}\text { Female } \\
\text { (Mean) }\end{array}$ & Mean & $\begin{array}{l}\text { Standard } \\
\text { deviation }\end{array}$ & Number \\
\hline 16 & 2.1 & 2.1 & 2.1 & 1.5 & 41 \\
17 & 2.6 & 1.7 & 2.1 & 1.8 & 42 \\
18 & 2.2 & 1.5 & 1.8 & 1.0 & 40 \\
19 & 1.6 & 1.3 & 1.5 & 1.1 & 44 \\
20 & 1.3 & 1.5 & 1.4 & 1.3 & 41 \\
21 & 1.8 & 1.0 & 1.5 & 2.2 & 44 \\
All ages & 1.9 & 1.6 & 1.73 & 1.7 & 252 \\
\hline
\end{tabular}

The risk of becoming infected increases with each new partner and particularly so if that partner is a member, or has previously had sexual intercourse with a member, of a high risk group. ${ }^{7}$ The proportion of the sample who consider themselves bisexual or homosexual is small in comparison with 1940s USA Kinsey data ${ }^{4}$ and may reflect the prevalence in a rural community.

Once the virus is established in the heterosexual community, people who are highly sexually active will 
fan its spread. In the survey, however, the number of highly sexually active 16-21 year olds is small. Only $5 \%$ of the sample of 400 had four or more partners in the 12 months; about $1 \%$ had had more than 30 partners in the 12 months. However of those who had four or more partners in this time $83 \%$ said they would probably not use a condom during their next sexual intercourse and half were uninterested in further information about AIDS.

The risk of catching HIV through sexual intercourse from an infected person varies with the frequency of intercourse, infectivity and the use of precautions such as the condom. ${ }^{8}$ There is little knowledge about infectivity between young heterosexuals. ${ }^{9}$ However, assuming a risk of between $0 \cdot 1 \%$ and $1 \%$ of infection with each sexual contact, and using the information on sexual behaviour obtained in this survey of an average number of 62 sexual intercourses per year and a duration of sexual partnership of 0.59 years, the average transmission risk per new (infected) partner lies between 0.036 and 0.31 .

With a transmission risk for a new partner of 0.31 and a frequency of partner change of $1 \cdot 1$ per year, the eventual prevalence could reach levels greater than those predicted in Knox's model for males and females, with transmission risks of 0.025 and 0.25 respectively and partner changes of 0.7 and 0.6 respectively, which were calculated as 15 and 66 HIV positive cases per 1000 . For those people sexually active (with a mean partner change rate of 1.7 per year) the risk of HIV infection will be higher, perhaps as high as 24 and 98 per 1000 for males and females respectively. Knox's predictions assume significant interaction between low risk and high risk groups, and no condom use. High levels of promiscuity were not identified in the Somerset survey, but the level of sexual intercourse found could, if transposed to areas where high risk groups live, produce the levels of prevalence indicated. Ranging from 15 to 100 per 1000 , they are of the same order of magnitude as rates found in recent African surveys in general and antenatal populations. ${ }^{10}$.

For the majority of young people in Somerset, sexual intercourse takes place within the context of a steady relationship. Only a minority $(18 \%)$ have had more than one sexual partner in the last year. Choosing that partner and making sure the partner is free from infection are the dilemmas facing young people today. To help them, most are asking for more AIDS information and discussion, undertaken in small groups of mixed sex, with the availability of expert knowledge at hand. ${ }^{5}$ Given the onset of sexual experience among young people in Somerset there is a clear need to provide education about AIDS at an early age.

This survey indicates that, without dramatic changes in the rate of the aquisition of new partners, frequency of intercourse and condom usage, sexual behaviour in this country is more conducive to the spread of the disease than had hitherto been supposed. For, even in an area thought to have relatively few members of high risk groups, if the transmission risk is assumed to be $1 \%$ per sexual contact with an infected partner, then the current levels of intercourse $(62 \%$ per year) and partner change (1.7 per year) would increase the prevalence of HIV infection eightfold in 5 years. However, prevalence would increase only by about $35 \%$ in 5 years if transmission risk is taken as $0.1 \%$ per sexual contact. Initially the risk of HIV infection from a new partner who is not in a high risk group will be very small, but the risk will increase each year. An accurate assessment of this risk requires more detailed knowledge of infectivity through heterosexual activity and current prevalence rates.

The authors would like to acknowledge the valuable contributions made by Professor Larry Jenson (Brigham Young University, Utah, USA) who provided useful insights concerning adolescent behaviour and attitudes, Christine Gunter (IPS) for the computer analysis and Dr Paul Ewings (SHA) for statistical advice.

This work was supported by a grant from the South Western Regional Health Authority.

Address for correspondence and reprints: $\mathrm{Dr}$ Cameron Bowie, Director of Community Medicine, Somerset Health Authority, County Hall, Taunton, Somerset TA1 4EJ.

\section{References}

${ }^{1}$ Anonymous. AIDS and sex [Editorial]. Lancet 1988; i: 31.

2 Isham V. Mathematical modelling of the transmission dynamics of HIV infection and AIDS: a review (with discussion). $J R$ Stat Soc A 1988; 151: 5-49.

${ }^{3}$ Knox EG. A Transmission model for AIDS. Eur $J$ Epidemiol 1986; 2; 165-77.

${ }^{4}$ Kinsey AC, Pomeroy WB, Martin CE. Sexual behaviour in the human male. Philadelphia: WB Saunders \& Co, 1948.

${ }^{5}$ Ford N. A survey of the AIDS awareness and sexual behaviour and attitudes of young people in Somerset. University of Exeter: Institute of Population Studies, 1988.

${ }^{6}$ Hyde JS. Understanding human sexuality. London: McGraw Hill, 1986.

${ }^{7}$ Moss AR. Epidemiology of AIDS in developed countries. Br Med Bull 1988; 44: 56-57.

${ }^{8}$ Friedland GH, Klein RS. Transmission of the human immunodeficiency virus. $N$ Eng $J$ Med 1987: 317; 112535.

${ }^{9}$ Dietz K. Models of transmission in a heterosexual population. In: Future trends in AIDS. London: HMSO, 1987.

${ }^{10}$ Piot P, Carael M. Epidemiological and sociological aspects of HIV infection in developing countries. Br Med Bull 1988; 44: 68-88.

Accepted for publication September 1988 